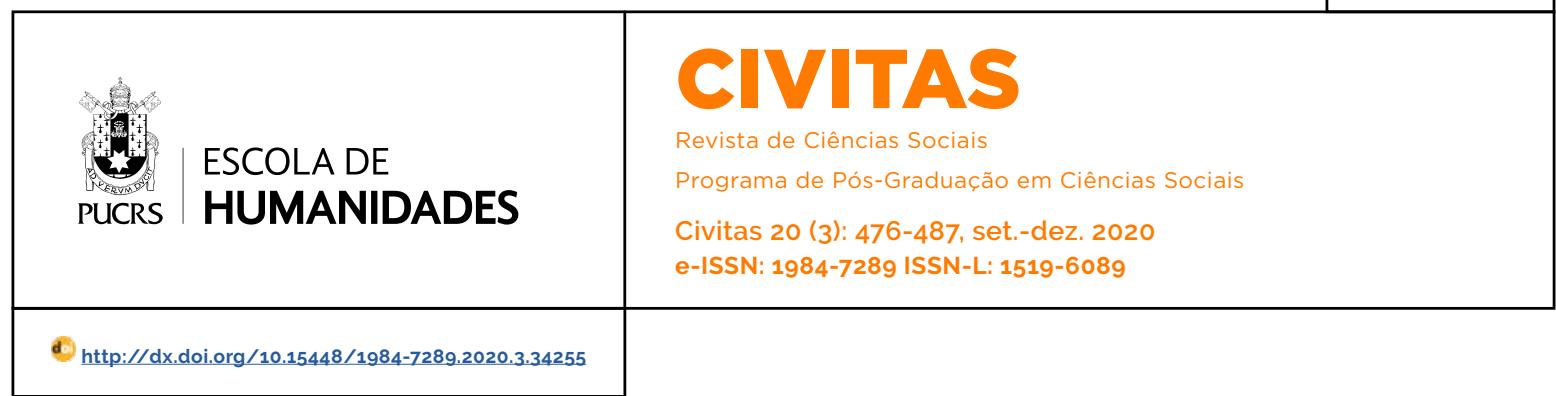

ARTICLES/ARTIGOS

\title{
過労死 (Karōshi)'s phenomenon and its collective existential damage
}

\author{
O fenômeno do Karōshi e seu dano existencial coletivo
}

El fenómeno del Karōshi y su daño colectivo existencial

\section{Lauro Ericksen ${ }^{1}$}

orcid.org/0000-0002-4195-1799

laurooliveira@trt21.jus.br

Received: 24 May 2019

Accepted: 14 Oct. 2019

Published: 23 Dec. 2020

\section{(c) (1)}

Artigo está licenciado sob forma de uma licença Creative Commons Atribuição 4.0 Internacional.
Abstrac: This paper discusses 過労死 (Karōshi)'s phenomenon, stating it as a social labor-related issue. It presents Karōshi as sudden death by overworking. This paper objective consists in showing it as a singular and particular case of Japanese workaholism, rooted in its own cultural work system, conceptualizing Karōshi as a singularity in Japanese cultural system, putting it, and also 過労自殺 (Karōjisatsu), as an existential damage beyond the individual worker. Karōshi surpasses the line of personal damage and can be considered a cultural collective damage.

Keywords: Labor Law. Fundamental Rights. Overwork death (Karōshi). Existentialism. Existential damage.

Resumo: Debate o fenômeno do 過労死 (Karōshi), enquadrando-o como um problema social relacionado ao trabalho. Apresenta-o como uma morte súbita decorrente do (excesso) de trabalho. Apresenta o Karōshi como uma forma particular e singular de workaholismo japonês, enraizado em sua própria sistemática de trabalho. Conceitua o Karōshi como uma singularidade da cultura japonesa e como um dano existencial para além do evento individual da morte do trabalhador. Conclui que o Karōshi e, também o Karōjisatsu, perpassam a linha da pessoalidade do dano e devem ser tidos como uma forma de dano existencial coletivo. Palavras-chave: Direito do trabalho. Direitos fundamentais. Morte por excesso de trabalho (Karōshi). Existencialismo. Dano existencial.

Resumen: Debate el fenómeno del 過労死 (Karōshi), encuadrándolo como un problema social relacionado con el trabajo. Presenta-lo como una muerte súbita derivada del trabajo. Presenta el Karōshi como una forma particular y singular de trabajo japonés, arraigada en su propia sistemática de trabajo. Concibe el Karoshi como una singularidad de la cultura japonesa y como un daño existencial más allá del evento individual de la muerte del trabajador. Concluye que el Karōshi, también el Karōjisatsu, atravesa la línea de la personalidad del daño y debe ser tratado como una forma de daño existencial colectivo.

Palabras clave: Derecho del trabajo. Derechos fundamentales. Muerte por exceso de trabajo (Karōshi). Existencialismo. Daño existencial.

\section{Introduction}

The paper intends to debate a specific labor environmental phenomenon called 過労死 (romanized as Karōshi), the death by overwork or job-related exhaustion, and its major effect, named 過労自殺 (Karōjisatsu) a suicidal behavior followed up by a psychological labor disturbance. 過労死 is a mix of two Japanese words, which one represented by one Kanji (a Japanese syllabic phoneme): 過労 (karō, "overwork") + 死 (shi, "death"). It is a recent 
labor phenomenon, which came up on the late 70's (its first register) and it is usually identified as an important social problem in Asian culture, mainly in Japan, where it has been recorded and discussed for the first time and then made popular.

The theme is something intriguing, and not quite discussed on academic fields (at least in Brazil) and deserves a deeper approach. So, the main objectives of this paper are not only to conceptualize the main aspects of Karōshi, just describing it, but also presenting this social issue as a very singular cultural problem, and as a form of collective existential damage. Thus, the most challenging aspect (and its main objective as well) consists in showing Karōshi not just as a single issue of the capitalist way of production and work (at least not just something like that, even though it can be described as a capitalist deformity as well), but as a whole existential problem of a singular culture, its own customs at work and in its own in its own labor environment. The cultural element will be the key to comprehending why Karōshi is a social issue related only to Japan, and only possible of happening inside Japanese work culture.

To proceed with such hard methodological task, we intend to mix a philosophical-existentialist theory core referral with international labor law statutory interpretation and factual descriptions.

Since Karōshi is not a disease or a health issue itself, the first step (premise) of present analysis is to bring a sole concept of this phenomenon, linking its description to labor environmental aspects and defining its main occurrences, such as common characters, repetition data, usual recurrence and other similar facts. The International Labor Organization (ILO) ${ }^{2}$ has a pivotal article (technical tool) often used to measure if a labor routine is (or is not) considered to be able to provoke a Karōshi status, or even unfold into Karōjisatsu. The mentioned existential theoretic aspect shall be used in order to present Karōshi in a conjectural and collective context, showing its wide spreading damage, which may attack and reach employees on its maximum feature and overtaking others, such as family, work mates and the whole society in general. This methodology combination is a key element to achieve the paper's proposed objectives.

The described theme should be didactically organized into two more sections. The next one shall bring the concept, description and general occurrences of Karōshi paying special attention to the Karōjisatsu effect which is the ultimate and finishing line of the whole Karōshi labor process. The other section shall be devoted to making the coalition of these labor law aspects with the existential and collective damage caused by Karōshi, trying to explain how this labor issue reproduces itself in a very suitable induced and prolific cultural medium

\section{過労死 (Karōshi) and 過労自殺 (Karōjisatsu): culture, work and death in Japan}

Literally, in a free form textual translation, Karōshi means overwork death, despite not being a disease itself, it is the social factor for heart, cerebral, vascular problems or ischemic heart disease. As firstly described by Hosokawa, Tajiri and Uehata $(1982,5)$, Karōshi is a:

[...] condition of being permanently unable to
work or dead due to accurately attacking ische-
mic heart disease such as myocardial infraction,
or accurate heart failure caused by cerebral
vascular diseases (CDV's) such as cerebral
hemorrhage, subarachnoid hemorrhage and
cerebral infraction, because inherit health pro-
blems such as hypertension and arteriosclerosis
are deteriorated by excessive work overload.

It is correct to declare that "Karōshi is understood as cerebral and/or cardiac disease, or death resulting from cerebral and/or cardiac disease, "triggered" or "induced" by excessive fatigue accumulation due to overwork" (Okudaira 2004, 206). The relationship between overwork, health problems and complications is the nuclear aspect in Karōshi definition.

This clinical and medical description shows how severe and harmful Karōshi is described in

\footnotetext{
2 Ilo. n. d. Karōshi: Death from Overwork. Accessed February 16, 2018. http://www.ilo.org/safework/info/publications/WCMS_211571/ lang--en/index.htm.
} 
medical literature and the specialized media. Along those lines, another very solid medical description of Karōshi indicates that it is:

[...] a cause and effect relationship between work and illness, life-threatening health statuses caused by the exacerbation of existing conditions such as high blood pressure and arteriosclerosis due to unsound health practices brought on by overworking (Morioka 2008, 5).

It is a social-medical term, established by physicians and lawyers, although there are no official or government endorsed studies or statistics, the "Hotline Network" compilation case report shows that the organization received nearly 5,000 requests for counselling in June, 1998 and almost half of these requests resulted in actual deaths (Ishida 2004, 220). Karōshi is a symbol of overworked Japan and it contrasts itself with astonishing economic growth and development achieved after World War II, then, it symbolizes the tension and distress of a hyper-industrialized and secularized communitarian society (Inoue 1993, 531). Karōshi and Karōjisatsu's main difference from other ordinary experiences of overwork on other countries and cultures, is that they certainly lead to death.

At this point, in order to amplify the social scenario, it is urgent to bring some definitions stated on an ILO (2013) article published in 2013. for "World Day for Safety and Health at Work". The article "Karōshi: Death from overwork", gathers key information from Japanese official reports about Karōshi to state 4 (four) usual causes and make a brief description of Karōshi as well. Allnight, late-night or holiday work, both long and excessive hours are the most common causes of Karōshi, companies tend to reduce the number of employees and have the same amount of work (North 1994, 56). Excruciating long-term labor time extensions (continuous overtime workdays) are commonly reported as a usual work routine on Karōshi cases. The excess of overtime is the major element on Karōshi description.

Karōshi necessarily indicates employer negligence: "care, which seems to be such a central part of human life, is treated as so marginal a part of existence" (Tronto 1993, 111).
Neglecting employees' safety and health is one of the most ominous and villainous way of suppressing workers' fundamental rights, a way of killing them symbolically and literally. Karōshi occurrences imply a crystal clear "evidence of employer failures to sincerely fulfill the social responsibility incumbent upon them to care for subordinates' well-being" (North ans Morioka 2016, 61). If employees' health and safety were one of the top index and concerns of employers, no case of violence, neglected health problems or any other risk situations involving work environmental aspects would be noticed.

Stress accumulated due to frustration at not being able to achieve the goals set by the company is another cause. The stress is even more accentuated by the culture of 世 間 (Seken), or the "public gaze" (others' opinions about one's behavior). Seken is a sociological thought and possesses a religious meaning (in Buddhism) designating private feelings and intimate compassion (Ogino 2013, 97). It was increasingly aggressive in Japanese culture after World War II due to the process of transformation into a private society of business interests dominated by steadily growing consumption, mass production and industrialization: a universal but undemocratic, in essence, process (Hein 2009, 66). The cultural heritage of Seken mixed with the wild and aggressive form of industrial capitalism put into shape after WW II created a social and pernicious pressure on Japanese workers.

The third cause is forced resignation, dismissal, and bullying, or better put, the terror and the fear of these acts of rejection on labor environment. This is the main reason why "some companies resorted to bullying and harassment of middleaged employees to force them to voluntarily resign" (Clegg and Bailey 2008, 747). To prevent, or to be ahead of the events, some employees anticipate the effects of dismissal or resignation and express Karōshi's "symptoms".

The last probable cause for Karōshi is the occurrence of "middle management". This business term stands for "intermediate management of a hierarchical organization that is subordinate to 
the executive management and responsible for at least two lower levels of junior staff" (Aucoin 1990, 91). Regarding the transitional figure middle managers occupy, they are responsible for implementing company policies in the most efficient way, but, as much as they do so, they also suffer with these policies. In a vicious cycle, they are agents and patients (semi-executive position, subordination and duties make them a hybrid type of employee) of the labor environment they are in charge of creating, they inflict and suffer the effects of Karōshi as much as they are the same cause of such phenomenon.

Work rate and productiveness may vary a lot, from person to person, gender to gender, age to age, therefore, it is correct to say that: "the relationship between work hours and mental and physical health is not linear" (Kuroda and Yamamoto 2016, 16). Yet, surely, "working more than 50 hours per week notably erode mental health of workers" (Kuroda and Yamamoto 2016. 17). Nowadays, in Japan, in order to being approved for the mental illness of workers' compensation insurance caused by work related factors, and to avoid new lawsuit cases as well, the current standard criteria requires workers to prove that he or she worked more than 160 hours of overtime work for the most recent month or more than 120 hours of overtime work per month for the last several consecutive months (Kawahito 2014, 38). It is a regression, in comparison to 2004's Japanese health labor programs, which stated the maximum of 100 extra hours in a single month or the maximum of 80 extra hours in a sequence of months, minimum of 3 (three) months in a row, at least. ${ }^{3}$ The related regression on worker's fundamental rights is a large gap on extra worked hours, a fact which encourages Japanese companies to keep carrying on their oppressive overworking policy.

The most susceptible group of Karōshi is the so called サラリーマン (in the original writing set in
Katakana, spelled "Sararīman" - or Salaryman in a Romanized version). Salaryman are low-mid class businessmen. They are the symbol of Japanese masculinity and corporate culture itself as they are full-time white-collar employees of organizations offering the guarantee of lifetime employment, salaries and promotions linked to length of service, and an ideology of corporate paternalism characterizing their labor relationship (Dasgupta 2014, 255). Becoming a Salaryman denotes success in Japanese culture, and a typically good Salaryman mean absolute adherence to the corporation which dedicated itself to the nation's industrialization and modernization. Hence, the loyalty being to such an extent that the amount of work is actually taking their lives: death by overwork - Karōshi (Adachi 2013, 127). Salaryman are either afraid to say "no" to overwork practices or do not think about other working systems (they are not open to ideas somewhat different from their Japanese Production Management - JPM). Additionally, the level of work devotion of a Salaryman is so extremely high that if he shows even the slightest interest in his family, his evaluation will suffer considerably (Hamao 1997. 90). Their career must be built upon "selfsacrifices" and "loyalty", "service overtime" is taken for granted for being a good Salaryman, and their work routine is inhumane, for such overload of work. When they do not commit as expected they are an object of sneer, derision, and mockery, being ridiculed, smirked and chaffed for not being able to achieve high loyalty expectations. The "bad Salaryman" is scoffed by his superiors all the time and ends up to be fired.

Both Karōshi and Karōjisatsu phenomena are the extreme ending of a worker's life; indeed, they are the end of everything. This is an important point and it should be effectively highlighted: there is no after Karōshi - or Karōjisatsu. It means, literally, (sudden and unannounced) death, nothing else matters after that. Sometimes, when this theme

\footnotetext{
3 MHLW (Ministry of Health, Labour and Welfare). 2004. White Paper on the Labor Economy. Tokyo: Gyosei. Accessed February 16, 2018. http://www.mhlw.go.jp/english/wp/l-economy/2013/dl/01.pdf.

MHLW (Ministry of Health, Labour and Welfare) 2013 平成24年度「㨫・心臟疾患と精神障害の労災補償状況」まとめ(Workers'compensation payments for brain and heart disease and mental illness). Accessed January, 12 2018. http://www.mhlw.go.jp/stf/houdou/2r$98520000034 \times n o . h t m !$
} 
is discussed, this annihilation aspect seems to be a little bit left behind, as if Karōjisatsu would be a recoverable status or a reclaimable reality of a single employee's standing view of poor working conditions. And, in fact, this is not what it really is, there is no recoverability in this kind of phenomena: it is ultimate and bygone. By all means, yet slightly different, Karōshi and Karōjisatsu can be considered as cut from the same cloth; they only differ in its execution, but share the same twisted and ominous hard working origin.

One of the best descriptions summarize 過 労自殺 (Karōjisatsu) as: "suicide resulting from overwork-related harassment and/or depression" (North and Morioka 2016, 60). Another very good summarizing concept is given by Kawahito (2014. 25): "Karōjisatsu has been recognized as a work related accident by the law only when the work is the cause of mental disorder and the worker loses the rational ability to evaluate suicide". In its concept, Karōjisatsu differs from Karōshi in its nature and in its direct derivation. Karōjisatsu is the main cause of events; instead, it can be considered an effect of Karōshi, it can be one of the final possibilities of death by overworking.

Both are derived from a cultural context of excess of work and are found among workers in all jobs and all age groups (Kumazawa 2010, 50). It is a pacific standpoint deeply discussed on this paper, but their derivation is different. Meanwhile Karōshi is direct answer of worker's body to labor environmental sickness, Karōjisatsu is the psychological derivation of Karōshi's happening, and, for sure, an indirect effect of Japanese cultural overworked oppressive model of production and management (the so called JPM). Both phenomena are accrued from work, and more specifically, from a sick work environment, from oppressive labor routines, systems and organization - a tort law legal assumption duty (Hanami and Komiya 2011, 147) -; but, they differ radically on some aspects, and these differences shall be mooted ahead.

Similar to Karōshi's description, ILO (2013) also provided, in the same article, a brief appraisal of Karōjisatsu. The document describes Karōjisatsu as: "Long work hours, heavy workloads, lack of job control, routine and repetitive tasks, interpersonal conflicts, inadequate rewards, employment insecurity, and organizational problems could become psychosocial hazards at work". It really sounds almost the same as Karōshi's main causes, despite focusing more on the subjectivity projection of work about him or herself, the named "employment insecurity", a broad term that includes a lot of branches and derived aspects.

Mental disorders and mental illnesses are usually reported as predictors of suicide, it is a pre-constituted context to induce several ways of self-inflicted harm, and it may end on the ultimate act of killing yourself (Harris and Barraclough 1997, 206). All mental disorders - excepting mental retardation and dementia, which are not linked-up with Karōjisatsu phenomenon in any case at all - have a strong association and a potential effect with suicide attempts, increasing the suicide risk on mentally challenged people. It is the kickstarting point to understanding how mental health problems can be associated to job stress, long hours working and strenuous work environmental elements.

In general cases of suicide, it is listed that almost $50 \%$ of the victims leave suicidal notes or any other kind of message (Hoberman and Garfinfel 1988, 690). The statistics are very similar, not to say they are the same, for the cases of Karōjisatsu, as stated by Amagasa, Nakayama and Takahashi's $(2005,161)$ research. The most relevant discovery about these notes are the reasons of the self-inflicted violence.

Amagasa, Nakayama and Takahashi $(2005,162)$ developed a didactic scheme to explain the stage progressions of Karōjisatsu, they modeled the job progression to show a better comprehension of this theme. The affected subject departs from a not very good work-place environment: long hours and heavy workload. In spite of facing this kind of strenuous work environment, he/ she is able to obtain a promotion, transfer or personal reorganization (or any other sort of job progression). This job progression is considered a major event of his life, and it is endured under 
heavy pressure and long work-day hours, something between $10 \mathrm{~h}$ to $16 \mathrm{~h}$ on a daily basis. They established a $13 \mathrm{~h}$ average as a straight mark for manifestation of mental disorders. This manifestation might occur between 2 weeks or 8 months before the suicide event and between 5 weeks or 18 months after the promotion.

During the intersection time between manifestation of mental disorder (the depression outcome) and death, the worker experiences signs of exhaustion, thinks about retirement and even tries to make some changes in his life in order to improve his lifetime quality. Even though he/ she may try to change his/her lifestyle, there is a heavy force pushing his back to work, making a strong encouragement for better results and to achieve work goals. Sometimes the family tries to make the employee see how much work-centered he/she is, but this kind of attempt is in vain, the worker spends so much time in his/her workplace that it is almost impossible to disconnect from the stressful routine and long never-ending journeys. By this time, family connections seem to be ineffective, the only possibility of leverage to stop the Karojisatsu's cycle happens if they act before the job promotion, since this event has an unimagined magnitude on the worker's mind, and it is the breaking point for his downfall.

After the mental health disorder and depression mood gets a hold of the worker, his/her physical health tends to decrease, he/she stops exercising, lacks interests in sports or any other physical activities, not only for not having free time to do such things, but because their mind cannot process any joy during these activities. As long as it progresses, behavioral changes are more noticeable, bad mood is a continuous aspect of the worker's life, circadian circle is reversed or simply non-existent and the work time routine is crushing any other social aspect that he/she may have ever had in his lifetime at all. The worker tries suicide, and it is often achieved on the first attempt

The end of this life chapter is the commitment of suicide, the ultimate form of life despair and lack of hope. So, it is correct to assume that it is unlikely to prevent suicide without appropriate action from employers and the immediate family aid (Takahashi et al. 1998, 280). As much as the overworking context progresses, so does the family, getting away from daily living activities together and the harder the employer's actions become toward worker productivity and work ratio. So, instead of preventing suicide - Karōjisatsu these actions and behaviors just push it forward into happening; they are just a prelude to an announced tragedy of suicide from overworking until death eases the suffering.

Another element about Karōjisatsu that deserves to be highlighted is the cultural element of hesitation of Japanese physicians to diagnose depression on overworking employees (Üstün and Sartorius 1995. 47), and the medical inability to manage people suffering from depressive suicide feelings and contemplating the possibility (of a suicidal ending). So, besides the now reprised argument of the cultural JPM effect - the three major systematic aspects of lifetime employment, pay scale and seniority as loyalty (Amagasa; Nakayama, and Takahashi 2005, 163) -, there is also a prevalent argument on Japanese enclosure and shortcoming on mental disorders (derived from work) medical treatment. The cultural element is something that transcends the boundaries of a mere economic layer (the JPM) and flows toward other fields (medical and mental health care, in a broad aspect), spreading on to various sectors of Japanese society, being prevalent and unescapable; so, almost every worker is susceptible to a silent and omnipresent social/labor threat.

The last feature of Karōjisatsu - also Karōshi as well - shall be analyzed and discussed. It is the "legal benevolence" of the Japanese law system and Judiciary apathy towards judgements and convictions regarding it. Legally, aside from the Ministry of Health, Labor and Welfare papers, Japan has no legal definition or legal standard for the Karōshi and Karōjisatsu phenomena, there is a legal vacuum about this topic. Several Japanese studies, previously reported in this paper, point out the health limit of working hours, but there is no legal limitation. There are legal standards for developing diseases while engaged in work, as 
described in "Article 75 of the Labor Standards Law", or the "prescribed occupational diseases", listed in Attachment 1-2 of Article 35 of the Enforcement Regulations for the Labor Standards Law (Okudaira 2004, 206). But none of these legal elements are clearly relating overworked long hours to suicide/depression or ischemic and cardiovascular diseases. The legal relationship is not so apparent, so the causal nexus is yet to be deployed (on court).

Under Article 36 of the Labor Standards Law, overtime agreements can be concluded between management and the representatives of labor (unions). At a first glance, overtime is not allowed in Japan, but this kind of agreements (described in Article 36) makes possible to do as much overtime as management thinks it needs to achieve production targets (North and Morioka 2016, 75). The "MHLW" guidelines call for limiting overtime to under 45 hours per month or 360 hours per year, but their guidelines are not mandatory as law enforcement. The way overworking hours are discussed and enforced in Japan represents a flagrant and ominous vilification of workers' basic and fundamental rights to a healthy work-day measured time.

The legal problem does not rely only on Karōshi and Karöjisatsu's legislation; there is judiciary apathy on resolving the filed cases as well. This important issue of slowness and retarded outdate response is pointed out by Inoue and Matsumoto (2000, 284):

However, there has been no standard for its recognition, and in some cases it has taken around 5 years from submission of an application about a work related accident until a conclusion is reached, as the applications are assessed at an expert meeting of the Ministry of Labor on a one by one basis.

Judiciary slowness and apathy are a step back on Karōshi and Karōjisatsu better treatment, and a threat for all Japanese workers. The way it is treated by legal power in Japan puts all employees in a vulnerable position, as they are always subdued and powerless while facing JPM and other cultural elements of the Japanese labor system. There is no overrating in saying that Japanese workers are held hostage, in some overworking situation, and they have, basically, only two options: waiting for a sudden CDV caused death or trying to put an end to this suffering way of life. Both possibilities end up on the end of all possibilities, so, they are not a true chosen existential possibility in any way possible. They are just a simple flowing of continuous and torturous lifetime.

\section{An existential damage: cultural and collective elements in 過労死 (Karōshi) prevalence}

It is very important to impose that Karōshi is not just an isolated event, it is not just a sole and unfortunate happening in labor (law) field, something that happens and must remain with no (further) explanations. Karōshi has some deep and complex cultural relations with the whole society and the collective forms of human evolution and work organization are responsible for it, there is no way of getting away from this assertive line.

Some cultural and collective connections between Karōshi and its ominous, pernicious and hazardous effects are not so simplistic, they need a deeper form of explanation, and for this sake, some philosophical aspects shall be brought to this text, in order to clarify these connections, and in order to show how workers' existence is put on the edge with such forms of aggression. Besides, it is very important to assume the wide range of consequences Karōshi derived from the existential damage imposed to on the sole worker, which spreads collectively, in the cultural spectrum, being wider and greater than the single act of a worker's death, these are some philosophical question that should be answered on the following paragraphs of the current section.

To incept into the connection of philosophical elements and the labor law questions that surround this text, it is important to bring forth the existential content of Heidegger's lessons (1962). It shall be the theoretical north of this work, showing both the collective element of human interactions and the existential conduction and effect of Karōshi on human relationships.

The extension of Karōshi's outrageous effects transcends the mere individual aspect, mainly, 
because its genesis is thorn inside the very core of a disruptive management and production mode, previously discussed. Besides, this transcending extension of damages will cause (and its tort law repercussion as well), such as shall be explained later in this paper, a full existential damage, a kind of damage that inflicts the sole worker being in its own existence, as much as it ceases, and also harms the whole society as well, once the worker (conceived as a Dasein) is a being-with others (Mitsein).

To start the adequate comprehension of how wide the effects of Karōshi can be, it is mandatory to make some philosophical statements based on Heidegger's (1962) first phase of his thoughts, mainly based on the "Being and Time" masterwork. Man, taken in his fully and complete extension of ways of being and possibilities, is not determined "naturally" as it goes. There is no proper nature to define what man is, and what he is not, this is the main reason why Heidegger (1962) names him as Dasein, "this entity which each of us is himself and which includes inquiring as one of the possibilities of its Being" (Heidegger 1962, 27). Nevertheless, this term represents all existential possibilities of man, everything he can be or become as a "human being itself". So, Dasein is not predetermined in older definitions of what is to be a man, or how a man shall behave unto a whole world of possibilities.

Dasein holds what can be called a preontological comprehension of the world. It is the only living being able to uphold this kind of comprehension (Heidegger 1962, 32). The perception of the world and the way the things and others (Daseins) can be seen and perceived goes beyond the ontological way of "contact". So, the question of the being, and how Dasein is and how things can be, is the main question to be made, it is the pivotal question to philosophy and metaphysics. Dasein is able to conceive others and other things before they are actually something to the world, just because Dasein is Insein, or, a being-into-the-world. The world is not something given beyond the objects and how they simply are. This is how we have a preontological comprehension, to not perceive anything as something strange or out of the world which we are all thrown. This is why the Dasein exists, but other things (except other Dasein) simply are, but they never will be able to truly exist.

Heidegger (1962) may deny the truth as the "subject's truth", once he does not intend to compromise himself with some systematic concept of metaphysical tradition connecting "object" and "subject" (such as Descartes do). So Heidegger engender his efforts into characterizing truth as something close to man (Dasein) and not something put into the fact world, objectively speaking. Dasein lives and gets along with others, but truth is not an external thing for him, it is a part of itself, it's truly given itself (Ericksen 2017, 33). Truth, existence and everything else than can be afforded in a material way of discretion, such as happiness or sadness are given inside the world; nothing is externally provided to anyone who is described as a Dasein (everyone else to say, in any way possible). There is no external channel able to describe Dasein by itself, no natural cause can assert its existence into the world, just like if his/her own life was not yet to be lived. So, the only way to describe Dasein is by its own meanings, it is by its own comprehension of the world, unveiling the question of being, and all these errands and missions can be fulfilled by the mediation of culture.

The work environment and reality are a major part of the cultural world, as a being-in-the-world (in an In-Sein perception, as briefly described before). To think how man develops its key abilities and prowess is a cultural exercise, there is no human development departed from labor and work in any single possible way.

World and labor are two concepts deeply entwined; there is no way to tear them apart. This relation is better explained, philosophically, when it is stated that, for Hegel (2004) as for Heidegger: "being appears in producing itself" (Goldmann 1977. 50). The way man (or Dasein) produces itself is in the world and for the world. Taking decisions in front of possibilities (provided by the world) is the way man has to live on the weight of his own choices. The forms of relation between 
Dasein and the world are forms of incompletion, there is even something yet to be done, thus, man is never whole by itself, or, even for himself at last. Dasein is always projecting new ideas and new possibilities into the world, but it is a dimension not ever completed, never outlasted in its fullness at all. Regarding this subject, Andrew Feenberg $(1995$, 52) points that: "In Heidegger, the contingency of the relation of Dasein to the world is never overcome. At most Dasein's resoluteness enables it to be itself in the face of its 'thrownness'". Feenberg's conclusion stands that Dasein is continually facing his own decisions and projects, and the world and its diversity are never enough to embrace all possibilities, including the chosen ones and those which were left behind, even though both are equally valued, but never enough. Through labor, Dasein is able to get much closer to overcoming the world just by producing himself with others, in a way that his own existence named "being-with-others". It explains how important labor is in the construction of a collective identity of interaction between Dasein and others; it is a key aspect in the social life and designs a whole existential dimension.

Labor and work manners and dynamics are truly rooted in cultural schemes and other sorts of development mechanisms able to connect people to each other and to make every single production a part of a whole and interdependent system. This is how culture works and how each Dasein is not just an island of commiseration in its own existence. There are other instances of existence that go beyond the sole perception of (it) self; this is the main cultural medium of existence by preponderance. Work and labor are existential possibilities of Dasein while being-with-others, only while existing in this specific way of being, collectively, Dasein can perform its labor duties and social skills. While being-with-others Dasein gets occupied (with objects and instruments of labor) and preoccupied (with others like him, others Dasein are the reason of preoccupation, just because it is a pre-ontological form of caring, so it comes before anything else inside the social - world), in a particular existential instance.
Heidegger $(1962,307)$ divides the mode of being-with-others in two major stances of existential possibilities: an authentic form, solely named "being-with-others", and an inauthentic one, named Das Man, in German, or "the they", in English. He is not so clear about the authentic process of collective being-with-others, this is one major point that Karl Löwith highlights in his analysis, and it is amplified because Heidegger dodges any straightforward political disclosure on his texts (Górnisiewicz 2016, 95). The fact of not being so clear about collective authenticity is not a major issue for this work's purpose. It is more relevant to focus on the inauthentic form of collectiveness named "the they". It assumes a major role because this is the everyday form of living, the most repeating and common way of interacting with others. This is the form of beingwith-others where we can find labor relations and labor existential facts, in short, this is where and how the work environment is built.

Labor and other work-related issues are daily faced in an inauthentic facade of the world; this way of being-into-the-world is the inauthentic manner of usually dealing with others. There is no major existential aspect to be found in labor "praxis", even though it can be considered the way of developing the spirit, as pledges Hegel (2004), or one of the main forms of connecting people in its common errands and tasks. Describing the labor environment as an inauthentic form of living, is not equivalent to diminishing it in face of other forms of existential connections nor represents any kind of lower level of true social interactions.

One of the main explanations of this occurrence consists in the notion the world is always offering a myriad of possibilities, which are not always something that make Dasein think about his own final line of existence, or the so-called death. Once there is not always an urgent thinking about death, in a way Dasein is not always prevalent as a beingtowards-death. The most authentic way of facing existence is to place your own life in the horizon of your death, this is the most truly authentic form of living. However, this is not the most common and usual form of living, just because no one is 
ever thinking about death, $100 \%$ of the time, and, if it is happening, probably there is some mental illness involved in this systematic thinking of death.

The way towards death is the path of authenticity so pursued by Heidegger (1962, 279). The world, by itself, is never enough, it never is and never will be capable of making Dasein whole. The one and only possibility of being-a-whole is presented by death, or, in other words, in the way Dasein is able to face his own death. Here, Heidegger is not thinking about the natural process of death, as a simple fact, urgent by its own time. He is thinking about death in an existential context, death means the end of all possibilities, the end of being anything, but, in the same way, the event of death can bring wholeness to the being. Nothing misses or can be missed beyond death, there is a state of being that speaks against all possibilities, everything that is whole is complete, does not misses or loses any of its parts, it is fulfilled by its perfection. This is the existential aspect of death Heidegger wants to present.

It is a major aspect to explain how Dasein can face authenticity by death because if death comes in an earlier stage of life, in an authentic manner, without the possibility of being whole, which comes in the blink of an eye (Heidegger 1962, 434), an outrageous existential damage is happening. Basically, living as "the they" undercovers any possibility of being-towardsdeath, but when death comes by working, and by living inauthentically with others, the damage done is beyond repair. It would be different if Dasein would always live authentically, always facing its own death, as a whole, nothing will be extraordinary, and even death would not be considered a strange thing. But, taking the labor environment as a good example, the event of death caused by overworking is an existential damage, something that cuts off any possibility of being authentic at all, a visceral and lashing hit on Dasein's existence.

Characterizing Karōshi as an existential damage is the major intent of this essay. Karōshi is also displayed in a cultural formation, something very similar to "the they" daily basis construction of
Heidegger, it is place into falling and represents the decadence of labor world in its core. Karōshi is only detectable in collective groups and labor associations, it is culturally developed (the Japanese culture is where it reaches its peak) and represents an irreparable damage to the worker's existence, mainly, because it suddenly ceases all possibilities into nothingness.

So, thrown into the falling and decadence of "the they", there is not much left for a worker inside Karōshi's system, the way death will be faced is in an inauthentic manner, in a sick environment, with an incommensurable damage to its own existence. To support Karōshi is to annihilate any form of authentic form of living, individual or collective speaking.

\section{Conclusions}

Karōshi is a very complex phenomenon and a huge existential damage to the labor world. It can be considered a vicious and pernicious way of organizing labor structures and its damages are countless. Going beyond its medical conditions and physical aspects, so much was debated and scrutinized in the second section of this paper, it is very important to bring out the collective and the cultural elements of Karōshi, without such cultural base, there is no way of comprehending its main aspects and concepts, and the reason for that resides in the fact that Karōshi is not a simple and unfortunate fact, not just a sad occurrence in the labor environment.

The other key element on Karōshi's construction is the JPM, the Japanese model for management and work. Despite being true to say that JPM catalyzes this overworking input to demand even more work and extra dedication. JPM also has brought the figure of the middle manager, which gathers together characteristics of two sides, employers and employees, mixing them together, demanding more loyalty, more work, and sometimes a true devotion towards labor. The middle manager is charged with extraordinary demands, even harder shifts of work and is also responsible for collecting and demanding a high level of production and work commitment from their subordinates. This way of 
organizing and structuring the work environment is a JPM signature; it is a way to implement the work rate and to make it faster and cheaper as well. As we can see, when these practices are focused and incorporated on daily basis production, one of the probable results is Karōshi and its derelicts effects on human health, making the workplace ill and even leading to suicide, the also discussed before Karōjisatsu.

Karōshi by definition demands a sudden death occurrence, but, one of its effects is named Karōjisatsu. Karōjisatsu means the suicide solution taken over Karōshi, it has a major mental instability aspect, which differs from the ordinary sudden death by overworking defined by Karōshi. Karōjisatsu is a confused state of mind, in which the workers finally put an end into his suffering by killing himself. As any other mental disturbance, it is not a rational and well thought decision to commit to the extreme act of suicide, it is, nonetheless, a cry for help, a desperate act of delusion and a hopeless decision caused by the same elements that cause Karōshi. Even though mental disorders can have multiple roots and complex associated elements, it is true to say Karōjisatsu possesses a deep rooted aspect on the work place or environment and a close relation to overtime working hours (and possibly other work related issues, such as moral harassment, for example).

It is easy to assume how pernicious and harmful to workers' fundamental rights Karōshi is. Since it is so harmful, the pivotal intent of this paper is to conceptualize it as an existential damage by itself, something cultural and collective developed but inflicted right into the worker's existence. The usual perspective of falling and decadence experienced by "the they" is the plain and simple background for Karōshi prevalence. So, in this philosophical and existential perspective, Karōshi inauthentically damages the worker, ripping off any other authentic form of living, either individually or collectivelly. Karōshi corrupts non-harmful forms of being-withothers, bringing sudden and unexpected death to workplaces and environments.

Finally, it is important to say Karōshi should be prevented in order to preserve a healthy work environment, free from long overtime hours and never ending shifts. It is a way of protecting the most fundamental right attained to any work in general, its health. More than that, it is a way of preserving its probability to an authentic existence, which cannot be harmed by such existential damage. And, if it occurs and it is diagnosed, it should be indemnified as such, with heavy punitive (existential) damages attached to it in order to prevent it in the future.

\section{References}

Adachi, Setsuko. 2013. A monolinguistic identity in transculturality: japanese and multi-lingualism. In Intersecting identities and interculturality: discourse and practice, edited by Regis Machart, Lim Choon Bee, Lim Sep Neo, and Eriko Yamamoto, 111-129. Newcastle: Cambridge Scholars.

Amagasa, Takashi, Takeo Nakayama, Yoshitomo Takahashi. 2005. "Karōjisatsu" in Japan: characteristics of 22 cases of work-related suicide. Journal of Occupational Health 47 (1): 157-164. https://doi.org/10.1539/joh.47.157.

Aucoin, Peter. 1990. New public management: Canada in comparative perspective. Montreal: Institute for Research on Public Policy.

Clegg, Stewart and James Bailey. 2008. International encyclopedia of organization studies. v. 1. London: Sage.

Dasgupta, Romit. 2014. Salaryman anxieties in Tokyo sonata: shifting discourses of state, family and masculinity in post-bubble Japan. In Gender, nation and state modern Japan edited by Andrea Germer, Vera Mackie, and Ulrike Wöhr, 255-284. New York: Routledge.

Ericksen, Lauro. 2017. Angústia, verdade e subjetividade: Kierkegaard influenciando Heidegger. Dissertatio 45 (1): 24-45. https://doi.org/10.15210/dissertatio.v45i0.10028.

Feenberg, Andrew. 1995. Alternative modernity. Berkeley: University of California Press.

Goldmann, Lucien. 1977. Lukács and Heidegger: towards a new philosophy. London: Routledge.

Górnisiewicz, Arkadiusz. 2016. Existentialism as a political problem in Karl Löwith's thought. History of European Ideas 42 (7): 951-964. https://doi.org/10.1080/019165 99.2016.1161538.

Hamao, Yokota. 1997. 浜田市銀人の家庭本会 (Misfit banker's diary on family breakdown). Tokyo: Kadokawa Shoten.

Hanami, Tadashi, and Fumito Komiya. 2011. Labour law in Japan. Alphen aan den Rijn: Kluwer.

Harris, Clare and Brian Barraclough. 1997. Suicide as an outcome for mental disorders: a meta-analysis. The British Journal of Psychiatry 170 (3): 205-28. https://doi. org/10.1192/bjp.170.3.205. 
Hegel, Georg. 2004. Die philosophie des Rechts. Frankfurt am Main: Suhrkamp.

Heidegger, Martin. 1962. Being and time. Oxford: Blackwell.

Hein, Patrick. 2009. How the Japanese became foreign to themselves: the impact of globalization on the private and public spheres in Japan. Münster: LIT.

Hoberman, Harry and Barry Garfinkel. 1988. Completed suicide in children and adolescents. Journal of the American Academy of Child \& Adolescent Psychiatry 27 (1): 689-695. https://doi.org/10.1097/00004583198811000-00004.

Hosokawa, Migiwa, Seiichiro Tajiri, and Tetsunojo Uehata. 1982. Karōshi: approval of cerebral and cardiovascular diseases as occupational disease and how to prevent them. Tokyo: Rodo Keizawashi,

Inoue, Tatsuo. 1993. The poverty of rights-blind communality: looking through the window of Japan. Brigham Young University Law Review 193 (2): 517-551.

Inoue, Kanji and Mao Matsumoto. 2000. 過労自殺 (suicide from overwork): a spreading occupational threat. Occupational and Environmental Medicine. 57 (1): 284285. https://doi.org/10.1136/oem.57.4.284a.

Ishida, Makoto. 2004. Death and suicide from overwork: the japanese workplace and labour law. In Labour law in an era of globalization: transformative practices and possibilities, edited by Richard Michael Fischl and Joanne Conaghan, 219-232. 2 ed. Oxford: Oxford UP.

Kawahito, Hiroshi. 2014. 過労自殺 (Karōjisatsu). 2 ed. Tokyo: Iwanami Shoten.

Kumazawa, Makoto. 2010. 働きすぎに斃れて: 過労死 · 過労自殺の語る労働史 単行本 (Collapsing from overwork: a labor history that karōshi and karōjisatsu tell). Tokyo: Japan: Iwanami Shoten.

Kuroda, Sachiko and Isamo Yamamoto. 2016. Workers' mental health, long work hours, and workplace management: evidence from workers' longitudinal data in Japan. Rieti Discussion Paper Series. 16 (17): 1-34. https:// www.rieti.go.jp/jp/publications/dp/16e017.pdf.

Morioka, Rika. 2008. Anti-karoshi activism in a corporate-centered society: medical, legal, and housewife activist collaborations in constructing death from overwork in Japan. San Diego: University of California.

North, Robert Scott. 1994. Karōshi and the politics of workers' compensation in Japan. Manoa: University of Hawaii Press

North, Robert Scott and Rika Morioka. 2016. Hope found in lives lost: karōshi and the pursuit of worker rights in Japan. Contemporary Japan 28 (1): 59-80. https://doi. org/10.1515/cj-2016-0004.

Ogino, Masahiro. 2013. Structuralism, post-structuralism and thereafter. In Routledge companion to contemporary Japanese social theory: from individualization to globalization in Japan today, edited by Anthony Elliott. Masataka Katagiri, and Atsushi Sawai, 94-111. New York: Routledge.
Okudaira, Masahiko. 2004. Karōshi (death from overwork) from a medical point of view. Japan Medical Association Journal 47 (5): 205-210. https://www.med. or.jp/english/journal/pdf/jmaj/v47no05.pdf.

Takahashi, Yoshitomo, Hideto Hirasawa, Keiko Koyama, Akira Senzaki, and Kyoko Senzaki. 1998. Suicide in Japan: present state and future directions for prevention Transcultural Psychiatry 35 (1): 271-289. https://doi. org/10.1177/136346159803500206.

Tronto, Joan. 1993. Moral boundaries: a political argument for an ethic of care. London: Routledge.

Üstün, Tevfik Bedirhan and Norman Sartorius. 1995 Mental illness in general health care. Chichester: John Wiley and Sons.

\section{Lauro Ericksen}

Professor at the Centro Universitário Facex (UniFacex), Natal, RN, Brazil, in graduate program on Law and Work Process. PhD in Philosophy (2016) from the Universidade Federal do Rio Grande do Norte, Natal, RN, Brazil. Degree in Law (2008) at the Universidade Federal do Rio Grande do Norte (UFRN) in Natal, RN, Brazil. Studies in Law and Work Process (2010) at the Universidade Cândido Mendes in Rio de Janeiro, RJ, Brazil. Public servant at the Tribunal Regional do Trabalho 21. 